\title{
Double venipuncture is not required for adequate S-100B determination in melanoma patients
}

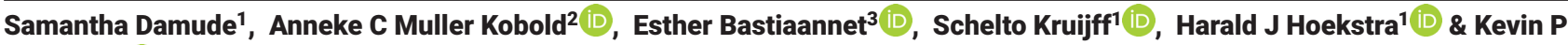
Wevers*,1 iD

${ }^{1}$ Department of Surgical Oncology, University of Groningen, University Medical Center Groningen, Groningen, The Netherlands; ${ }^{2}$ Department of Laboratory Medicine, University of Groningen, University Medical Center Groningen, Groningen, The Netherlands; ${ }^{3}$ Department of Surgical Oncology, University Medical Center Leiden, University of Leiden, Leiden, The Netherlands; *Author for correspondence: k.p.wevers@isala.nl

BioTechniques 69: 371-378 (November 2020) 10.2144/btn-2019-0147

First draft submitted: 5 November 2019; Accepted for publication: 4 August 2020; Published online: 25 September 2020

\section{ABSTRACT}

S-100B is used in melanoma follow-up. This serum biomarker is also present in adipocytes; therefore, subcutaneous adipocytes trapped in the needle before performing a venipuncture could contaminate the serum. The aim was to study the influence of adipocyte contamination on blood samples used for S-100B analysis, possibly resulting in falsely elevated S-100B values. A total of 294 serum samples were collected from 147 American Joint Committee on Cancer staging stage III melanoma patients. The mean difference between the first (dummy) and second tubes was $0.003 \mu \mathrm{g} / \mathrm{l}(\mathrm{p}=0.077)$, with a decrease in the second tube. Compared with the second tube, the S-100B level was higher in the first tube in $33.3 \%$ of the samples, equal in $36.8 \%$ of the samples and lower in $29.9 \%$ of the samples. No significant difference between the two consecutively drawn tubes was found. There seems to be no necessity of implementing a dummy tube system for accurate S-100B determination in melanoma patients.

\section{METHOD SUMMARY}

A dummy tube system was introduced for performance of venipunctures during regular follow-up in all American Joint Committee on Cancer staging stage III melanoma patients with no evidence of disease. After venipuncture, a dummy tube was drawn first, and subsequently the regular tube was drawn. The first tube was anonymously coded and stored, whereas the second tube was registered in the patients' medical results. After performing the assay, S-100B levels between the two consecutively drawn samples were compared.

\section{KEYWORDS:}

adipocytes $\bullet$ biological tumor markers $\bullet$ clinical laboratory techniques $\bullet$ melanoma $\bullet$ S100B protein

The biomarker S-100B is increasingly used and has important clinical value in screening, monitoring and predicting prognosis of melanoma patients [1-3]. Intracellular S-100B concentrations are usually high in disseminated melanoma (American Joint Committee on Cancer [AJCC], stage IV), and serum levels may be elevated [1,4]. The potentially aggressive and unpredictable character of melanoma strengthens the clinical desire to detect the first signs for disease progression as early as possible [5]. In some national melanoma guidelines (Germany, Switzerland), routine measurement of serum S-100B values is recommended $[6,7,8]$. However, melanoma studies that have tried to use S-100B for recurrence detection and prediction of sentinel node metastasis encountered problems due to the low sensitivity in these melanoma patients with minimal tumor load $[9,10]$. Another frequently encountered problem with biomarkers is the undesirable presence of false-positive and false-negative results [11]. For instance, patients' BMI and different comorbidities are associated with influencing serum S-100B values [11,12]. Multiple studies reported adipocytes to contain high levels of S-100B [13-19]. Determination of serum S-100B values in melanoma patients is performed by drawing a blood sample through a venipuncture and subsequent analysis of S-100B by immunoassay. Accurate determination and interpretation of serum S-100B is of high importance, especially in melanoma patients, where even minor changes of serum S-100B might have important clinical consequences. Diagnostic errors, like false-positive results, may lead to unnecessary anxious patients, potential hazardous overstaging and treatment, or even malpractice, accompanied with psychological trauma and increased healthcare costs [2].

Recently, S-100B values were found to be falsely elevated when mixed with subcutaneous cells, suggesting that adipocytes trapped in a venipuncture could affect the S-100B level [20]. The risk for this adipocyte contamination might especially be high in difficult venipunctures with longer subcutaneous routes, or after several attempts with the same needle. Hypothetically, adipocyte contamination only affects the first tube, as the needle will be flushed after drawing the first sample. The aim of this study was to test whether subcutaneous adipocytes cause falsely elevated S-100B values in blood samples of melanoma patients in routine venipunctures, and to study clinicopathological factors that might influence serum S-100B levels. 


\section{Materials \& methods}

Study design \& patients

At the University Medical Center Groningen, follow-up with regular intervals for all AJCC stage III and IV melanoma patients, with currently no evidence of disease, consists of medical history, physical examination and determination of S-100B. To determine whether contamination by adipocytes would increase S-100B values in a serum sample after a routine venipuncture, two subsequent tubes were drawn for S-100B analysis in all patients. Patients with local or distant metastases were excluded for analysis.

All venipunctures were performed by trained phlebotomists. Blood samples were collected by venipuncture of one of the veins in the anterior cubital fossa of the elbow (median cubital vein, basilica vein or cephalic vein), using a 40-mm 18-G needle in 8.5-ml yellow-top serum-separating Vacutainer tubes (Becton Dickinson, Plymouth, UK). A 'dummy' tube was drawn first, after which the 'regular' tube was drawn during the same puncture. A difficult venipuncture was defined by a prolonged subcutaneous route of $1 \mathrm{~cm}$ or more before entering the vein, or when several attempts were done using the same needle. This was documented on the case record form by the phlebotomists. To prevent any potential indistinctness regarding the test results, the first tube was coded, whereas the second tube was registered under the patients' data. After routine centrifugation, serum was separated from the tubes. Both tubes were equally analyzed in the same laboratory.

The study was conducted in accordance with the Declaration of Helsinki and conforms to the guidelines of the central medical ethics committee (METc2015.215). Characteristics of the patients, the primary tumors, sentinel lymph node biopsy and completion lymph node dissection were collected in a database. The recorded parameters included age, sex, BMI, time since diagnosis, current AJCC stage, comorbidities, site of primary melanoma, histologic type, Breslow thickness, ulceration, mitotic rate (number of cells in mitosis per square millimeter), sentinel node metastasis and non-sentinel node metastases.

\section{S-100B analysis}

S-100B concentrations were routinely determined by performing the S-100B assay (Diasorin, Saluggia, Italy) on an ELISA Robot platform (DS2, Dynex Technologies, Magellan Biosciences, Worthing, UK) according to the manufacturer's protocol. The intra-assay coefficient of variation of the S-100B assay is $7 \%$ at levels of $0.04 \mu \mathrm{g} / \mathrm{l}(0.0028 \mu \mathrm{g} / \mathrm{l})$. The reference interval was determined by analysis of S-100B values in 120 healthy individuals (median 0.07; range $0.01-0.59$ ) and calculating the $95 \% \mathrm{Cl}$ according to the Clinical and Laboratory Standards Institute EP28-A3c guideline (formerly C28-A2), resulting in a reference cut-off value for the healthy population of $0.20 \mu \mathrm{g} / \mathrm{l}[21]$.

\section{Statistical analysis}

Sample size analysis for a two-sided test was performed on the difference in S-100B value between the first- and second-drawn serum samples, with a power $\beta=0.80$ and $\alpha=0.05$. The purpose was to test the nil hypothesis: no difference in $S-100 B$ value between the two consecutively drawn samples. A sample size of 84 serum samples in each group (total $n=168$ ) was required to prove a difference between the first- and second-drawn tubes of at least $0.05 \mu \mathrm{g} / \mathrm{l}$.

Statistical analyses were performed using IBM SPSS statistics version 22 (IL, USA). Descriptive statistics were used for data presentation. Differences between the sample groups were assessed for statistical significance $(p<0.05)$ using a paired $t$-test or Pearson correlation for the normally distributed differences and Kruskal-Wallis for not normally distributed values. Normality was tested by visual inspection of the histograms. There were no outliers in the cohort, so all samples were used. Possible factors of influence on S-100B level in the second tube were tested by univariate and multivariate linear regression analysis. All variables that were associated with the S-100B level in the second tube with a p-value $<0.15$ in univariate analysis were entered in a multivariable linear regression model.

\section{Results \& discussion}

Patients' characteristics

A total of 294 serum samples were collected from 147 AJCC stage III and IV melanoma patients during follow-up. Median age of the patients was 57 (range 26-86) years, 51\% were female and median BMI was 26.5 (range 18.1-54.5) kg/m². Median Breslow tumor thickness was 1.94 (range 0.60-27.0) mm, and median time since diagnosis was 56 (range 1-400) months. At time of S-100B determination, $39.4 \%$ were stage IIIA, $29.9 \% \mathrm{IIIB}, 23.1 \%$ IIIC and $7.4 \%$ stage IV (no evidence of disease). Comorbidities were present in $44.9 \%$ of patients, of which $19 \%$ were cardiovascular, $6.8 \%$ were pulmonary, $6.8 \%$ were other malignancy in the past, $3.4 \%$ were neurological and $8.8 \%$ were other comorbidities (arthritis, kidney disease, hyperparathyroidism, morbid obesity, lichen sclerosus, gout) (Table 1). In $2.0 \%(n=3)$ of the samples a difficult venipuncture was reported, and for $8.1 \%(n=12)$ a subcutaneous route of more than $1 \mathrm{~cm}$ was reported. Based on these small numbers, no significant relation was found between a reported difficult venipuncture and the S-100B level in the first tube, nor in the difference in S-100B levels in the two consecutively drawn tubes.

\section{Evaluation of adipocyte contamination by analyzing the difference of S-100B levels in two consecutively drawn tubes}

The two consecutively drawn serum samples showed median S-100B values of 0.05 (range $<0.02-0.28$ ) $\mu \mathrm{g} / \mathrm{l}$ for the first tube and 0.04 (range $<0.02-0.23) \mu \mathrm{g} / \mathrm{l}$ for the second tube (Figure 1). The mean difference between the first and second tubes was 0.003 (range $-0.08-0.15) \mu \mathrm{g} / \mathrm{l}(95 \% \mathrm{Cl}: 0.0004-0.0070, \mathrm{p}=0.077)$, showing a trend for slightly lower S-100B levels in the second tube. The absolute S-100B level measured in the first tube was higher in $33.3 \%(n=49)$ of the samples, equal in $36.8 \%(n=54)$ of the samples and lower 
Table 1. Clinicopathologic factors of the 147 American Joint Committee on Cancer stage III melanoma patients.

\begin{tabular}{|c|c|c|}
\hline Characteristic & $\mathbf{n}$ & $\%$ \\
\hline \multicolumn{3}{|l|}{ Age (years) } \\
\hline Median, range & $57,26-86$ & \\
\hline$<60$ & 84 & 57.1 \\
\hline$\geq 60$ & 63 & 42.9 \\
\hline \multicolumn{3}{|l|}{ Sex } \\
\hline Female & 75 & 51.0 \\
\hline Male & 72 & 49.0 \\
\hline \multicolumn{3}{|l|}{ BMI $\left(\mathbf{k g} / \mathbf{m}^{2}\right)$} \\
\hline Median, range & $26.5,18.1-54.5$ & \\
\hline \multicolumn{3}{|c|}{ Time since diagnosis (months) } \\
\hline Median, range & $56,1-400$ & \\
\hline \multicolumn{3}{|l|}{ Current AJCC stage } \\
\hline IIIA & 58 & 39.4 \\
\hline IIIB & 44 & 29.9 \\
\hline IIIC & 34 & 23.1 \\
\hline IV (NED) & 11 & 7.4 \\
\hline \multicolumn{3}{|l|}{ Comorbidities } \\
\hline None & 81 & 55.1 \\
\hline Cardiovascular & 28 & 19.0 \\
\hline Pulmonary & 10 & 6.8 \\
\hline Neurological & 5 & 3.4 \\
\hline Other malignancy & 10 & 6.8 \\
\hline Other & 13 & 8.8 \\
\hline \multicolumn{3}{|l|}{ Histologic type } \\
\hline Superficial spreading & 95 & 64.6 \\
\hline Nodular & 31 & 21.1 \\
\hline Other & 9 & 6.1 \\
\hline Unknown & 12 & 8.2 \\
\hline \multicolumn{3}{|l|}{ Breslow thickness (mm) } \\
\hline Median, range & $1.94,0.6-27.0$ & \\
\hline \multicolumn{3}{|l|}{ Ulceration } \\
\hline No & 91 & $61.9 \%$ \\
\hline Yes & 38 & $25.9 \%$ \\
\hline Not reported & 18 & $12.2 \%$ \\
\hline \multicolumn{3}{|l|}{ Mitosis } \\
\hline No & 8 & $5.4 \%$ \\
\hline Yes & 123 & $83.7 \%$ \\
\hline Not reported & 16 & $20.9 \%$ \\
\hline \multicolumn{3}{|l|}{ Positive SLNB } \\
\hline No & 16 & $10.9 \%$ \\
\hline Yes & 82 & $55.8 \%$ \\
\hline Not performed & 49 & $33.4 \%$ \\
\hline \multicolumn{3}{|l|}{ Positive CLND/TLND } \\
\hline No & 45 & $41.7 \%$ \\
\hline Yes & 63 & $58.3 \%$ \\
\hline
\end{tabular}

than in the second tube in $29.9 \%(n=44)$ of the samples. As shown by the scatterplot in Figure 2, a bilateral (measurement) variance of $0.04 \mu \mathrm{g} / \mathrm{l}$ is seen (Figure 2). The positive outliers greater than $0.04 \mu \mathrm{g} / \mathrm{l}, 4.1 \%(\mathrm{n}=6$ patients) of the samples, had a mean age of 58 years, $33 \%$ were female, with a mean BMI of $29.7 \mathrm{~kg} / \mathrm{m}^{2}$ and $50 \%$ had cardiovascular comorbidities. Overall, no significant relation was found between age, sex, BMI or comorbidity and the difference in S-100B level between the two tubes (Table 2).

\section{Determination of patient factors associated with S-100B serum level in the second tube}

Both the first and second tubes were tested, with quite similar results. Therefore, only the results of the second, clinically relevant, tube are reported here. By performing univariate linear regression analysis, a significant association between S-100B level and patient or tumor characteristics was found for BMI $(p=0.005)$ and the presence of another malignancy $(p=0.005)$. A higher BMI was associated with a relatively higher serum S-100B level (Table 3 ). The presence of another malignancy (e.g., meningioma, endometrial cancer, breast cancer, non-Hodgkin and colon cancer) resulted in a slightly lower S-100B level $(0.02 \mu \mathrm{g} / \mathrm{l})$. Patients with comorbidities of cardiovascular, pulmonary or neurological origin showed no significant difference in S-100B levels (Table 4). 


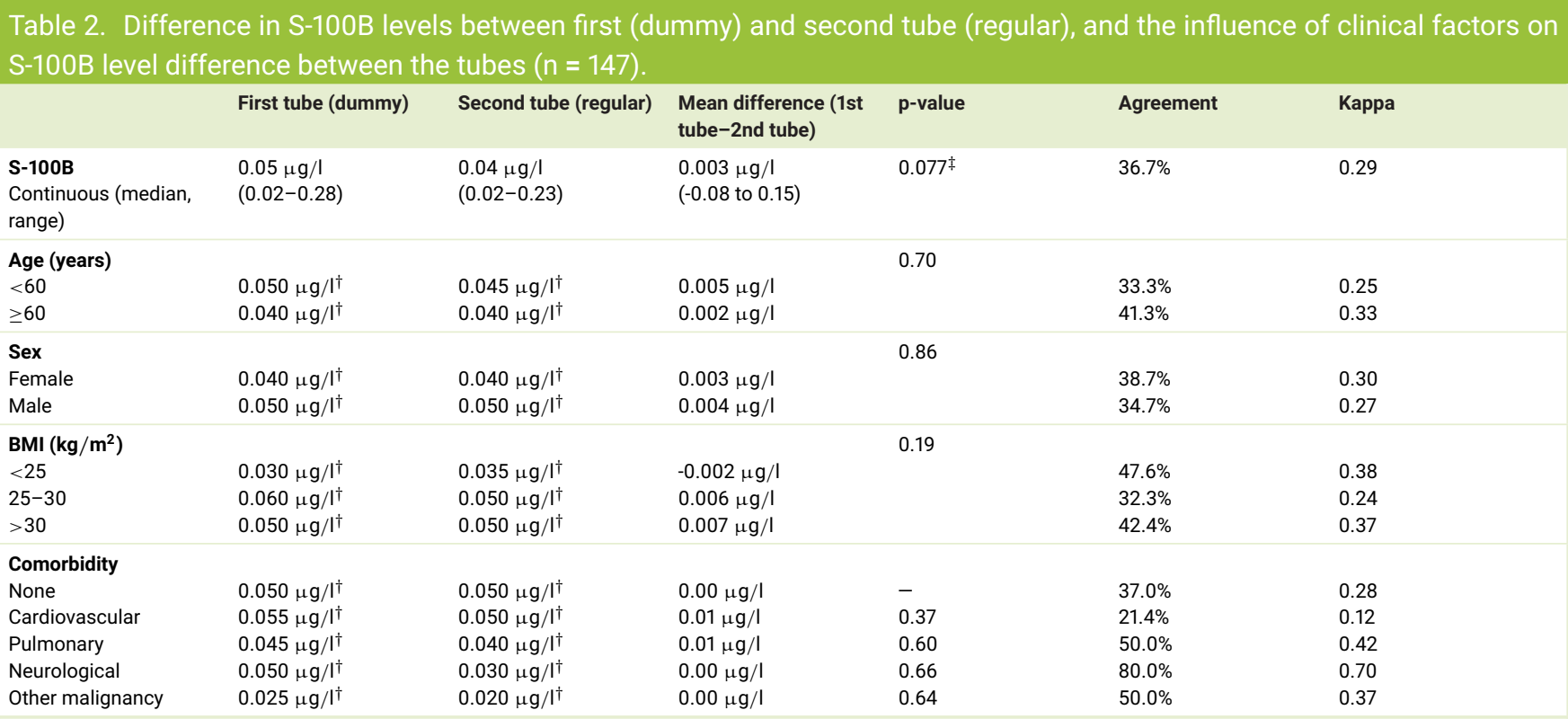

$\dagger$ Median values.

¥Paired $t$-test for difference between the first and second tubes. Pearson correlation or Kruskal-Wallis test for influence of clinical factors on S-100B level difference, where age and BMI were tested as continuous variables.

Table 3. Association of clinical factors with S-100B level in the second, clinically relevant, tube $(n=147)$.

\begin{tabular}{|c|c|c|c|c|}
\hline Characteristic & Second tube (median) & Coefficient & $95 \% \mathrm{Cl}$ & p-value \\
\hline \multicolumn{5}{|l|}{ Age (years) } \\
\hline$<60$ & $0.45 \mu \mathrm{g} / \mathrm{l}$ & -0.00002 (continuous) & $-0.0005-0.0005$ & 0.93 \\
\hline$\geq 60$ & $0.04 \mu \mathrm{g} / \mathrm{l}$ & & & \\
\hline \multicolumn{5}{|l|}{ Sex } \\
\hline Female & $0.04 \mu \mathrm{g} / \mathrm{l}$ & -0.011 & $-0.023-0.0004$ & 0.11 \\
\hline Male & $0.05 \mu \mathrm{g} / \mathrm{l}$ & Reference & & \\
\hline \multicolumn{5}{|l|}{ BMI $\left(\mathbf{k g} / \mathbf{m}^{2}\right)$} \\
\hline$<25$ & $0.04 \mu \mathrm{g} / \mathrm{l}$ & 0.013 (continuous) & $0.005-0.022$ & 0.005 \\
\hline $25-30$ & $0.05 \mu \mathrm{g} / \mathrm{l}$ & & & \\
\hline$>30$ & $0.05 \mu \mathrm{g} / \mathrm{l}$ & & & \\
\hline \multicolumn{5}{|l|}{ Current AJCC stage } \\
\hline IIIA & $0.04 \mu \mathrm{g} / \mathrm{l}$ & Reference & & 0.16 \\
\hline IIIB & $0.06 \mu \mathrm{g} / \mathrm{l}$ & -0.015 & $-0.041-0.011$ & \\
\hline IIIC & $0.04 \mu \mathrm{g} / \mathrm{l}$ & 0.008 & $-0.018-0.035$ & \\
\hline IV (NED) & $0.05 \mu \mathrm{g} / \mathrm{l}$ & -0.011 & $-0.038-0.017$ & \\
\hline \multicolumn{5}{|l|}{ Histologic type } \\
\hline Superficial spreading & $0.04 \mu \mathrm{g} / \mathrm{l}$ & Reference & & 0.26 \\
\hline Nodular & $0.04 \mu \mathrm{g} / \mathrm{l}$ & 0.014 & $-0.001-0.029$ & \\
\hline Other & $0.04 \mu \mathrm{g} / \mathrm{l}$ & -0.007 & $-0.032-0.017$ & \\
\hline \multicolumn{5}{|l|}{ Breslow thickness (mm) } \\
\hline$<1$ & $0.05 \mu \mathrm{g} / \mathrm{l}$ & Reference & & 0.65 \\
\hline $1-2$ & $0.05 \mu \mathrm{g} / \mathrm{l}$ & 0.002 & $-0.018-0.022$ & \\
\hline$>2$ & $0.04 \mu \mathrm{g} / \mathrm{l}$ & -0.003 & $-0.023-0.017$ & \\
\hline \multicolumn{5}{|l|}{ Ulceration } \\
\hline No & $0.05 \mu \mathrm{g} / \mathrm{l}$ & Reference & & \\
\hline Yes & $0.04 \mu \mathrm{g} / \mathrm{l}$ & 0.002 & $-0.006-0.011$ & 0.13 \\
\hline \multicolumn{5}{|l|}{ Mitosis } \\
\hline No & $0.05 \mu \mathrm{g} / \mathrm{l}$ & Reference & & \\
\hline Yes & $0.04 \mu \mathrm{g} / \mathrm{l}$ & -0.007 & $-0.033-0.019$ & 0.38 \\
\hline \multicolumn{5}{|l|}{ Positive SLNB } \\
\hline No & $0.04 \mu \mathrm{g} / \mathrm{l}$ & Reference & & \\
\hline Yes & $0.05 \mu \mathrm{g} / \mathrm{l}$ & 0.008 & $-0.012-0.029$ & 0.49 \\
\hline \multicolumn{5}{|l|}{ Positive CLND/TLND } \\
\hline No & $0.05 \mu \mathrm{g} / \mathrm{l}$ & Reference & & \\
\hline Yes & $0.04 \mu \mathrm{g} / \mathrm{l}$ & 0.002 & $-0.012-0.017$ & 0.87 \\
\hline
\end{tabular}

Continuous variables are displayed in categories and were tested as continuous. p-values $<0.05$ are printed in bold.

AJCC: American Joint Committee on Cancer; CLND: Completion lymph node dissection; NED: No evidence of disease; SLNB: Sentinel lymph node biopsy; TLND: Therapeutic lymph node dissection. 


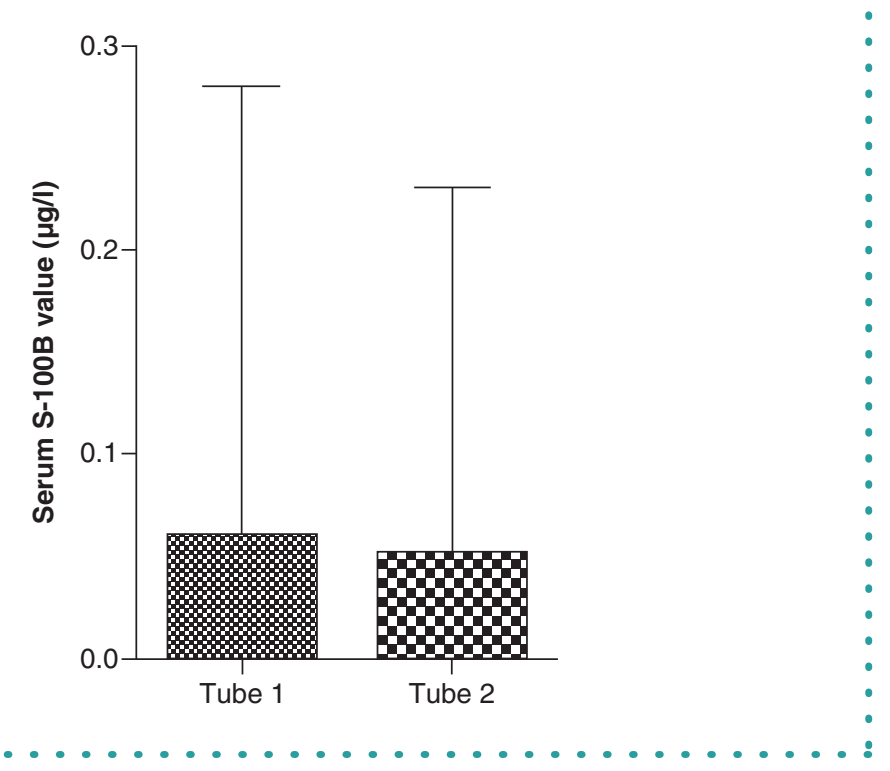

Figure 1. Mean serum S-100B value and range in first (dummy; $0.05 \mu \mathrm{g} / \mathrm{I}$ [range $0.02-0.28 \mu \mathrm{g} / \mathrm{I}])$ and second tubes $(0.04 \mu \mathrm{g} / \mathrm{I}$ [range $0.02-0.23$ $\mu \mathrm{g} / \mathrm{l}])$.

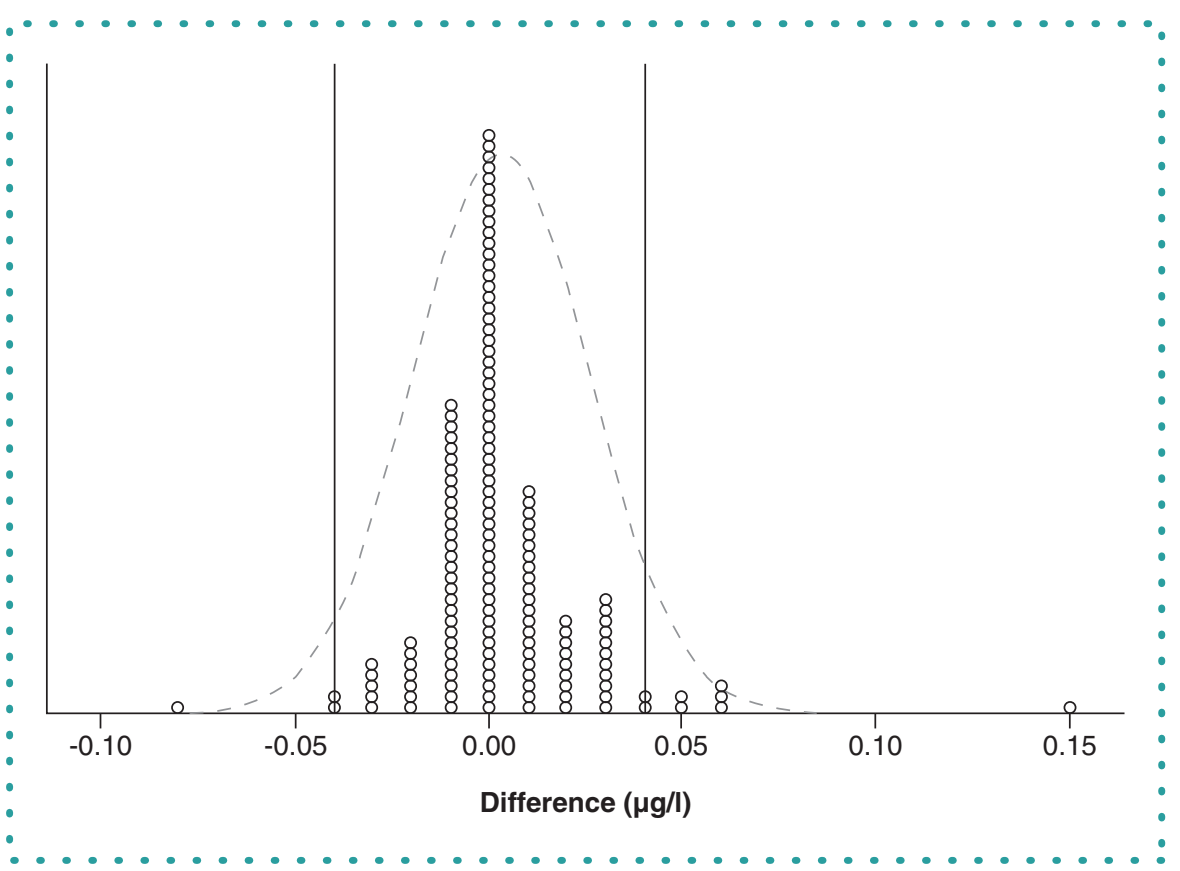

Figure 2. Difference of serum S-100B values between the two subsequently drawn tubes (first tube minus second tube). Descriptive statistics were used, resulting in a bilateral measurement variance of $0.04 \mu \mathrm{g} / \mathrm{l}$.

All variables that were associated with the S-100B level in the second tube with a p-value $<0.15$ in univariate analysis were entered in a multivariable linear regression model. In this model containing sex, BMI, ulceration and other malignant comorbidity, the following clinical factors were associated with the S-100B level on a $5 \%$ significance level: sex $(B=-0.021$ for male sex [ $95 \% \mathrm{Cl}$ : -0.035 to -0.006 ; $\mathrm{p}=0.006), \mathrm{BMI}(\mathrm{B}=0.002$ for higher $\mathrm{BMI}[95 \% \mathrm{Cl}: 0.000-0.003] ; \mathrm{p}=0.011)$, other malignancy $(\mathrm{B}=-0.026$ for presence $[95 \% \mathrm{Cl}:-0.052$ to -0.001$] ; p=0.041$ ) (Table 5).

This study was conducted to test the clinical impact of the previously described phenomenon of adipocyte contamination on the determination of serum S-100B levels [20]. The results of this study show that in individual patients, adipocyte contamination can result in falsely elevated S-100B levels, as six patients showed an S-100B level in the first tube greater than or equal to $0.05 \mu \mathrm{g} / \mathrm{l} \mathrm{higher}$ than in 


\begin{tabular}{|c|c|c|c|c|c|}
\hline Comorbidity & $\mathbf{n}$ & $\begin{array}{l}\text { S-100B second tube } \\
(\mu \mathrm{g} / \mathrm{I}) \text { (median, range) }\end{array}$ & Coefficient & $95 \% \mathrm{Cl}$ & $p$-value \\
\hline Cardiovascular & 28 & $0.05(0.0-0.14)$ & 0.005 & $-0.009-0.020$ & 0.36 \\
\hline Pulmonary & 10 & $0.04(0.0-0.11)$ & -0.011 & $-0.035-0.012$ & 0.32 \\
\hline Neurological & 5 & $0.03(0.03-0.07)$ & -0.004 & $-0.036-0.028$ & 0.74 \\
\hline Other malignancy & 10 & $0.02(0.0-0.05)$ & -0.029 & -0.051 to -0.006 & 0.005 \\
\hline Other ${ }^{\dagger}$ & 13 & $0.07(0.0-0.23)$ & & & - \\
\hline
\end{tabular}

Linear regression analysis; each comorbidity was tested independently. Bold represents a p-value $<0.05$

† Other comorbidities: arthritis, kidney disease, hyperparathyroidism, morbid obesity, lichen sclerosus, gout. This category was excluded for analysis.

\begin{tabular}{llll} 
Table 5. Multivariate linear regression model of clinical factors associated with S-100B level in second tube $(\mathrm{n}=147)$ & $\mathbf{p}$-value \\
Characteristic & $\mathbf{B}$ & $\mathbf{9 5 \%} \mathrm{Cl}$ & $\mathbf{0 . 0 0 6}$ \\
\hline Sex (male ref) & -0.021 & -0.035 to -0.006 & $\mathbf{0 . 0 1 1}$ \\
\hline $\mathrm{BMI}\left(\mathrm{kg} / \mathrm{m}^{2}\right)$ & 0.002 & $0.000-0.003$ & 0.95 \\
\hline Ulceration & 0.001 & $-0.015-0.016$ & $\mathbf{0 . 0 4 1}$ \\
\hline Other malignancy & -0.026 & -0.052 to -0.001 &
\end{tabular}

All factors with $p<0.15$ were entered in the multivariate analysis (enter methods). p-values $<0.05$ are printed in bold.

the second tube, which exceeds the analytical variation. However, the overall clinical impact of this finding in the follow-up measurement of melanoma patients seems to remain low.

According to the literature, the biology and the subsequent serum level of S-100 proteins is complex and multifactorial. The proteins are found to be tumorigenic by cell proliferation, metastasis, angiogenesis and immune evasion [12]. Besides being expressed by melanocytes in melanoma, S-100B is expressed by glial and Schwann cells, and multiple studies have described the presence of S-100B in adipocytes [14,22-27]. False-positive laboratory test results of S-100B caused by adipocytes in a blood sample have not been reported in literature before. Previously, our research group found a significant decrease of $0.198 \mu \mathrm{g} / \mathrm{l}$ in the second-drawn serum tubes in 20 healthy volunteers in which a difficult venipuncture was simulated by entering the vein after a $1.5-\mathrm{cm}$ subcutaneous route, suggesting a substantial contamination effect in the first-drawn tube [20]. The present study found no significant difference in S-100B levels between the two consecutively drawn tubes from 294 regular venipunctures in melanoma follow-up. With a p-value of 0.077 and a mean difference of $0.003 \mu \mathrm{g} / \mathrm{l}$, a trend could be considered with slightly higher S-100B values in the first-drawn (dummy) tubes. However, this overall difference does not seem clinically relevant. Despite this possible trend, the intra-assay variance should be taken into account as well, with a variance of $0.0028 \mu \mathrm{g} / \mathrm{l}(7 \%)$ for the S-100B assay. According to the scatterplot of differences (Figure 2), six patients seem to have an exceptionally big difference in S-100B levels, possibly representing the patients in whom adipocyte contamination did result in higher S-100B levels in the first tube (mean BMI $29.7 \mathrm{~kg} / \mathrm{m}^{2}$ ).

Some studies reported a correlation between serum S-100B and BMI, whereas others did not find this association $[11,13,28]$. Physiological S-100B levels in humans are found to be associated with adipose tissue mass. Therefore, elevated S-100B levels can even be found in apparently healthy individuals, especially in those with a high BMI [13]. In line with these previous studies, the current study did find a significant relation between the patients' BMI and the overall S-100B level in both tubes $(p=0.005)$, but not with the difference between the two consecutively drawn tubes $(p=0.19)$. In the present study, only one patient suffered from morbid obesity (BMI $54.5 \mathrm{~kg} / \mathrm{m}^{2}$ ), presenting with a relatively high S-100B level of $0.08 \mu \mathrm{g} / \mathrm{l}$. In two patients, S-100B values higher than the reference cut-off of $0.20 \mathrm{\mu g} / \mathrm{l}$ were found in both tubes; these patients had a BMl greater than $33 \mathrm{~kg} / \mathrm{m}^{2}$ and no radiological evidence of recurrent disease. Besides obesity, the literature reports that serum S-100B levels could be influenced by several other comorbid diseases, such as cardiovascular disease, liver cirrhosis, inflammatory disease and neurological disease $[11,12]$. The current study found no significant relation of comorbidities and S-100B levels.

This study was limited by the number of patients included and the number of blood samples taken. Although the sample size was sufficient to prove no difference between the first- and second-drawn tubes, some questions remain unanswered. Unfortunately, the risk for falsely elevated S-100B levels was not associated to whether or not the phlebotomist reported a difficult puncture in this study, as most venipunctures were reported to be uncomplicated and without a prolonged subcutaneous route, possibly due to experienced phlebotomists. In addition, no subgroup of patients could be identified in whom the appearance of adipocyte contamination was significantly higher. Besides the possible influence of patients' BMI, this study was not able to identify factors or comorbidities that are able to predict falsely elevated S-100B levels.

In conclusion, this study did not find a significant clinical impact of adipocyte contamination influencing serum S-100B values in regular melanoma follow-up serum samples. Although the risk of a falsely elevated S-100B value due to addition of adipocytes might still be present in difficult venipunctures, for apparent uncomplicated venipunctures the effect of adipocyte contamination seems to be negligi- 
ble. When used as a biomarker for melanoma patients, S-100B can safely be determined by venipuncture using a single tube. In case of strongly deviating or elevated S-100B values, however, careful interpretation is important and the clinician should consider the presence of erroneous results due to adipocyte contamination, as minor changes in serum S-100B levels might have clinical consequences, such as surgery or additional diagnostic tests. When false positivity is considered, a second tube could subsequently be drawn for accurate S-100B determination.

\section{Future perspective}

Although S-100B is currently used mostly (in combination with LDH) in stage IV melanoma patients to evaluate treatment response or disease progression, it might also be able to detect recurrence in asymptomatic stage III patients $[29,30]$. In case of a significant rise or elevation in two subsequent S-100B values during follow-up, FDG-PET/CT could be performed. By doing so, healthcare institutions are able to save on expenses by performing an expensive PET/CT only in specific high-risk patients. Future results will have to prove S-100B has the same or better detection capacity as PET surveillance for asymptomatic disease progression. Although promising, serum S$100 \mathrm{~B}$ might not be sensitive enough by itself as a basis for therapeutic decisions. For instance, a combination of S-100B and melanoma inhibitory activity protein might result in a higher sensitivity for predicting recurrence or disease progression [31]. Other biomarkers associated with prognostic information in melanoma are YKL-40, CRP and microRNAs [32-35]. Future research will have to reveal which biomarker or combination of biomarkers will be the most sensitive in different stages of melanoma.

\section{Ethical conduct of research}

The authors state that they have obtained appropriate institutional review board approval or have followed the principles outlined in the Declaration of Helsinki for all human or animal experimental investigations. In addition, for investigations involving human subjects, informed consent has been obtained from the participants involved.

\section{Author contributions}

S Damude, KP Wevers and AC Muller Kobold were responsible for study design and quality control of data and algorithms. S Damude and AC Muller Kobold were responsible for data acquisition. S Damude, KP Wevers, S Kruijff and E Bastiaannet provided data analysis and interpretation. S Damude, KP Wevers and E Bastiaannet provided statistical analysis. S Damude, KP Wevers and AC Muller Kobold prepared the manuscript. S Damude, KP Wevers and S Kruijff edited the manuscript. HJ Hoekstra, AC Muller Kobold and KP Wevers reviewed the manuscript.

\section{Financial \& competing interests disclosure}

The Groningen Melanoma Sarcoma Foundation supported this study. The authors have no other relevant affiliations or financial involvement with any organization or entity with a financial interest in or financial conflict with the subject matter or materials discussed in the manuscript apart from those disclosed.

No writing assistance was utilized in the production of this manuscript.

\section{Open access}

This work is licensed under the Attribution-NonCommercial-NoDerivatives 4.0 Unported License. To view a copy of this license, visit http://creativecommons.org/licenses/by-nc-nd/4.0/

\section{References}

1. Kruijff S, Hoekstra HJ. The current status of S-100B as a biomarker in melanoma. Eur. J. Surg. Oncol. 38(4), 281-285 (2012).

2. Wevers KP, Kruijff S, Speijers MJ, Bastiaannet E, Muller Kobold AC, Hoekstra HJ. S-100B: a stronger prognostic biomarker than LDH in stage IIIB-C melanoma. Ann. Surg. Oncol. 20, 2772-2779 (2013).

3. Smit LH, Korse CM, Hart AA et al. Normal values of serum S-100B predict prolonged survival for stage IV melanoma patients. Eur. J. Cancer 41(3), 386-392 (2005).

4. Guo HB, Stoffel-Wagner B, Bierwirth T, Mezger J, Klingmuller D. Clinical significance of serum S100 in metastatic malignant melanoma. Eur. J. Cancer 31A(11), 1898-1902 (1995).

5. Leiter U, Buettner PG, Eigentler TK, Forschner A, Meier F, Garbe $\mathrm{C}$. Is detection of melanoma metastasis during surveillance in an early phase of development associated with a survival benefit? Melanoma Res. 20(3), 240-246 (2010).

6. Cromwell KD, Ross MI, Xing Y et al. Variability in melanoma post-treatment surveillance practices by country and physician specialty: a systematic review. Melanoma Res. 22(5), 376-385 (2012).

7. Pflugfelder A, Kochs C, Blum A et al. Malignant melanoma S3-guideline "diagnosis, therapy and follow-up of melanoma". J. Dtsch. Dermatol. Ges. 11(Suppl. 6), 1-116 (2013).

8. Dummer R, Hauschild A, Lindenblatt N, Pentheroudakis G, Keilholz U. ESMO Guidelines Committee. Cutaneous melanoma: ESMO Clinical Practice Guidelines for diagnosis, treatment and follow-updagger. Ann. Oncol. 26(Suppl. 5), 126-132 (2015).

9. Egberts F, Momkvist A, Egberts JH, Kaehler KC, Hauschild A. Serum S100B and LDH are not useful in predicting the sentinel node status in melanoma patients. Anticancer Res. 30(5), 1799-1805 (2010).

10. Smit LH, Nieweg OE, Korse CM, Bonfrer JM, Kroon BB. Significance of serum S-100B in melanoma patients before and after sentinel node biopsy. J. Surg. Oncol. 90(2), 66-69; discussion 69-70 (2005).

11. Gebhardt C, Lichtenberger R, Utikal J. Biomarker value and pitfalls of serum S100B in the follow-up of high-risk melanoma patients. J. Dtsch. Dermatol. Ges. 14(2), 158-164 (2016).

12. Bresnick AR, Weber DJ, Zimmer DB. S100 proteins in cancer. Nat. Rev. Cancer 15, 96-109 (2015).

13. Steiner J, Schiltz K, Walter M et al. S100B serum levels are closely correlated with body mass index: an important caveat in neuropsychiatric research. Psychoneuroendocrinology 35(2), 321-324 (2010).

14. Goncalves CA, Leite MC, Guerra MC. Adipocytes as an important source of serum S100B and possible roles of this protein in adipose tissue. Cardiovasc. Psychiatry Neurol. 2010,790431 (2010). 
15. Kato K, Suzuki F, Nakajima T. S-100 protein in adipose tissue. Int. J. Biochem. 15(5), 609-613 (1983).

16. Suzuki F, Kato K. Induction of adipose S-100 protein release by free fatty acids in adipocytes. Biochim. Biophys. Acta 889(1), 84-90 (1986).

17. Netto CB, Conte S, Leite MC et al. Serum S100B protein is increased in fasting rats. Arch. Med. Res. 375(5), 683-686 (2006).

18. Steiner J, Bernstein HG, Schiltz K et al. Decrease of serum S100B during an oral glucose tolerance test correlates inversely with the insulin response. Psychoneuroendocrinology 39 (1), 33-38 (2014).

19. Kato K, Kimura S, Semba R, Suzuki F, Nakajima T. Increase in S-100 protein levels in blood plasma by epinephrine. J. Biochem. 94(3), 1009-1011 (1983).

20. Damude S, Niebling MG, Kobold AC, Hoekstra HJ, Kruijff S, Wevers KP. Adipocytes in venipunctures cause falsely elevated S-100B serum values. Clin. Chem. Lab. Med. 54(8), 235-237 (2016).

21. Horowitz GL. EP28-A3c: Defining, Establishing, and Verifying Reference Intervals in the Clinical Laboratory; Approved Guideline - Third Edition. Clinical and Laboratory Standards Institute, Wayne, PA, CLSI document EP28-A3c.

22. Stefansson K, Wollmann R, Jerkovic M. S-100 protein in soft-tissue tumors derived from Schwann cells and melanocytes. Am. J. Pathol. 106(2), 261-268 (1982).

23. Michetti F, Dell'Anna E, Tiberio G, Cocchia D. Immunochemical and immunocytochemical study of S-100 protein in rat adipocytes. Brain Res. 262(2), 352-356 (1983).

24. Barbatelli G, Morroni M, Vinesi P, Cinti S, Michetti F. S-100 protein in rat brown adipose tissue under different functional conditions: a morphological, immunocytochemical, and immunochemical study. Exp. Cell Res. 208(1), 226-231 (1993).

25. Holtkamp K, Buhren K, Ponath G et al. Serum levels of S100B are decreased in chronic starvation and normalize with weight gain. J. Neural Transm. 115(6), 937-940 (2008).

26. Hidaka H, Endo T, Kawamoto S et al. Purification and characterization of adipose tissue S-100b protein. J. Biol. Chem. 258(4), 2705-2709 (1983).

27. Buckman LB, Anderson-Baucum EK, Hasty AH, Ellacott KL. Regulation of S100B in white adipose tissue by obesity in mice. Adipocyte 3(3), 215-220 (2014).

28. Pham N, Fazio V, Cucullo L et al. Extracranial sources of S100B do not affect serum levels. PLoS ONE 5(9), e12691 (2010).

29. Beyeler M, Waldispuhl S, Strobel K, Joller-Jemelka HI, Burg G, Dummer R. Detection of melanoma relapse: first comparative analysis on imaging techniques versus S100 protein. Dermatology 213(3), 187-191 (2006).

30. Peric B, Zagar I, Novakovic S, Zgajnar J, Hocevar M. Role of serum S100B and PET-CT in follow-up of patients with cutaneous melanoma. BMC Cancer 11, 2407-2411 (2011).

31. Riechers A, Bosserhoff AK. Melanoma inhibitory activity in melanoma diagnostics and therapy-a small protein is looming large. Exp. Dermatol. 23(1), 12-14 (2014).

32. Krogh M, Christensen I, Bouwhuis M et al. Prognostic and predictive value of YKL-40 in stage IIB-III melanoma. Melanoma Res. 26(4), 367-376 (2016).

33. Fang S, Wang $Y$, Sui D et al. C-reactive protein as a marker of melanoma progression. J. Clin. Oncol. 33(12), 1389-1396 (2015).

34. Mumford SL, Towler BP, Pashler AL, Gilleard O, Martin Y, Newbury SF. Circulating microRNA biomarkers in melanoma: tools and challenges in personalised medicine. Biomolecules 8(2), 21 (2018).

35. Ankeny JS, Labadie B, Luke J, Hsueh E, Messina J, Zager JS. Review of diagnostic, prognostic, and predictive biomarkers in melanoma. Clin. Exp. Metastasis 35(5-6), 487-493 (2018). 